\title{
Identification of Sugarcane Striate Mosaic-Associated Virus by Partial Characterization of Its Double-Stranded RNA
}

\author{
Yoon Gi Choi, Barry J. Croft, and John W. Randles
}

First author: Department of Plant Pathology, University of California, Riverside 92521-0122; second author: Bureau of Sugar Experiment Stations, Old Cove Road, Woodford, Queensland 4514, Australia; and third author: Department of Applied and Molecular Ecology, University of Adelaide, Waite Campus, Glen Osmond, SA 5064, Australia. Accepted for publication 23 June 1999.

\begin{abstract}
Choi, Y. G., Croft, B. J., and Randles, J. W. 1999. Identification of sugarcane striate mosaic-associated virus by partial characterization of its double-stranded RNA. Phytopathology 89:877-883.

Sugarcane striate mosaic ( $\mathrm{ScSM}$ )-affected sugarcane leaves contain a disease-associated 9-kilobase (kb) double-stranded RNA (dsRNA), usually together with 6- and 2.6-kb dsRNAs. The purified 9-kb dsRNA was amplified by the randomly primed polymerase chain reaction (PCR) and cloned. The nucleotide sequences of three separate regions, representing about $2.55 \mathrm{~kb}(28 \%)$ of the dsRNA sequence, were found to have significant similarities to viruses in the genera Capillo-, Carla-, Fovea-, Potex-, Poty-, Tricho-, and Tymovirus. Greatest overall similarity was found to apple stem pitting virus, with less similarity to blueberry scorch virus and
\end{abstract}

ABSTRACT potato virus M. A standard virus purification procedure was used to identify slightly flexuous filamentous particles that copurified with the disease-associated RNA. Particle modal lengths were approximately 950 and $1,900 \mathrm{~nm}$ with a diameter of $15 \mathrm{~nm}$. Preparations contained a 51-kDa putative capsid protein and a 9-kb single-stranded RNA with a probable $3^{\prime}$ polyadenylate tract. These ScSM-associated virus particles differ physically from viruses in existing genera because of their relative rigidity, length, and putative coat protein size. Reverse-transcription PCR with a primer pair designed from the sequenced segments amplified a 820-base pair fragment from ScSM-affected but not healthy sugarcane plants.

Additional keywords: AMV, CF11, CMV, microgranular cellulose, phytoplasma, PSbMV, TMV.
Sugarcane striate mosaic ( $\mathrm{ScSM})$ is a severe disease of unknown etiology, first reported in 1961 in the sugarcane (Saccharum spp.) hybrid clones Pindar and Q56 in the lower Burdekin district of northern Queensland (12). Although its distribution is limited, the premature plough-out of fields with the disease leads to complete crop loss in affected areas, with annual losses of up to Australian $\$ 1$ million (6). Spread is slow, and evidence that the disease recurs on the same farms and that soil treatment with nematicidal and fungicidal fumigants reduces incidence (1) suggests that it is probably biotic and soilborne. It is transmitted by vegetative propagation, and cuttings from affected plants show symptoms when planted in other areas and environments. Heat treatment of cuttings does not cure symptoms (12), and the only available means of control is by the use of resistant cultivars.

Symptoms of the disease are characteristic short chlorotic striations on the lamina (Fig. 1) and stem. The youngest two leaves are usually symptomless. No virus has been found to be associated with the disease, but the syndrome (12) and a preliminary report that double-stranded RNA (dsRNA) could be isolated from affected sugarcane suggests that ScSM may have a viral etiology $(4,7)$. This article reports an investigation into the etiology of ScSM by the detection, isolation, cloning, and partial sequencing of a diseasespecific dsRNA, a preliminary classification of the putative viral agent from the partial sequence, the use of probes derived from the sequence to identify disease-associated filamentous particles, and the design of a diagnostic reverse-transcription polymerase chain reaction (RT-PCR) from the available sequence information.

Corresponding author: J. W. Randles; E-mail address: john.randles@ adelaide.edu.au

GenBank accession numbers of the ScSM-associated virus RNA sequences reported in Figure 3 of this paper are U57922, U57923, and U57924.

Publication no. P-1999-0820-01R

(C) 1999 The American Phytopathological Society

\section{MATERIALS AND METHODS}

Plant materials. The ScSM-affected and other sugarcane material used in this work was collected from sites near Ayr, Queensland. Seed from a disease-free source of cvs. Q96, Q117, and Q124 was provided by the Meringa Sugar Experiment Station of the Bureau of Sugar Experiment Stations (BSES); healthy cane of cvs. Q96 and Q117 and ScSM-affected cane of cv. Q96 were provided by BSES, Ayr; ScSM-affected leaves and canes from commercial properties were provided by growers Marshall (cv. Q96), Michelin (cv. Q96), Fava (cv. Q117), Pellizari (cv. Q117), and Ballao (cv. Q117). Seed, cane cuttings, and leaf samples were consigned by express mail. Leaves were stripped of midribs and stored at $-20^{\circ} \mathrm{C}$. Seedlings and cane cuttings were raised in the glasshouse at 25 to $30^{\circ} \mathrm{C}$ and fertilized with a complete nutrient mix biweekly.

dsRNA isolation. Fresh or frozen lamina tissue (100-g lots) with clear striations were chopped into pieces (approximately $5 \mathrm{~mm}$ square), placed in liquid nitrogen, ground briefly in a pestle and mortar, and then pulverized by blending in a VirTis homogenizer (The Virtis Company, Gardiner, NY) in liquid nitrogen. dsRNA was isolated either by the standard CF11 cellulose method according to Dodds (7) or by the microgranular cellulose batch method of Choi and Randles (5). The dsRNAs of alfalfa mosaic virus (AMV) and cucumber mosaic virus (CMV), tobacco mosaic virus (TMV), and pea seedborne mosaic virus (PSbMV) were extracted from inoculated Nicotiana glutinosa, N. tabacum, and Pisum sativum, respectively (7), and used as size markers. Analysis of preparations of dsRNA was done either in $6.5 \%$ polyacrylamide gels (acrylamide/bisacrylamide $=39: 1$ ) buffered in Tris-acetate-EDTA (TAE;

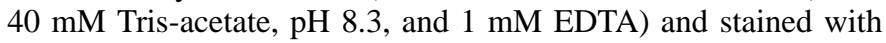
silver (21) or in agarose gels buffered with TAE and stained in aqueous 1-ppm ethidium bromide with fluorescent imaging at $254 \mathrm{~nm}$. dsRNA was purified after electrophoresis in a $0.9 \%$ agarose gel. The dsRNA band was excised and eluted with the RNaid Kit (Bio 101, Inc., La Jolla, CA). It was treated with RNase-free DNase I (Pro- 
mega Corp., Madison, WI) (5) and then with RNase A (100 $\mu \mathrm{g} / \mathrm{ml}$; Sigma Chemical Co., St. Louis) in high salt buffer $(0.3 \mathrm{M} \mathrm{NaCl}$ and $50 \mathrm{mM}$ Tris- $\mathrm{HCl}, \mathrm{pH} \mathrm{8.0)}$ for $1 \mathrm{~h}$ at $37^{\circ} \mathrm{C}$. This was followed by phenol-sodium dodecyl sulfate (SDS) extraction. The dsRNA was precipitated with isopropanol and then subjected to electrophoresis in a preparative $6.5 \%$ polyacrylamide gel using $N, N^{\prime}$-bisacrylcystamine (BAC; Bio-Rad Laboratories, Hercules, CA) as the crosslinker and buffered with Tris-borate-EDTA (TBE; $89 \mathrm{mM}$ Trisborate, $\mathrm{pH} 8.5$, and $2 \mathrm{mM}$ EDTA). After detection with ethidium bromide, the band was excised, the gel was dissolved by adding one-third volume of 2-mercaptoethanol to release the dsRNA (9), and microgranular cellulose was again used to bind and recover the dsRNA (5). Other precautions to minimize contamination with nucleic acids or nucleases included the omission of DNA size markers from all gels and the use of diethyl pyrocarbonate-treated sterile water.

cDNA synthesis. Denatured dsRNA was primed with a random hexanucleotide $(\mathrm{RH})$ linked to the $3^{\prime}$ end of a universal oligonucleotide (UN) that had an EcoRI site and an additional 5' sequence suitable for priming the PCR. Amplification of cDNA was done according to Froussard (10) with the following modifications. The sequence of the UN-RH primer was 5' GCCGGAGCTCTGCAGAATTCNNNNNN 3'. dsRNA ( $5 \mu$ l, approximately $50 \mathrm{ng})$ was mixed with $2.5 \mu \mathrm{M} \mathrm{UN}-\mathrm{RH}$ primer and incubated at $100^{\circ} \mathrm{C}$ for $10 \mathrm{~min}$, cooled to room temperature, and the reverse-transcription reaction setup (50 mM Tris-HCl, pH 8.3; $50 \mathrm{mM} \mathrm{KCl;} 10 \mathrm{mM} \mathrm{MgCl} ; 10 \mathrm{mM}$ dithiothreitol [DTT]; 40 units [U] of ribonuclease inhibitor [RNasin; Promega Corp.], $2 \mathrm{mM}$ dNTPs, and $200 \mathrm{U}$ of Moloney murine leukemia virus reverse-transcriptase [M-MLV-RT; Gibco BRL, Gaithersburg, MD] in a final volume of $50 \mu \mathrm{l}$ ). Following incubation at $43^{\circ} \mathrm{C}$ for $60 \mathrm{~min}$, the mixture was boiled for $5 \mathrm{~min}$ and chilled. Second-strand synthesis was done with Klenow DNA polymerase (10 $\mathrm{U}$ in $50 \mathrm{mM}$ Tris-HCl, $\mathrm{pH} 7.2 ; 10 \mathrm{mM} \mathrm{MgSO}$; $1 \mathrm{mM}$ dNTPs; and $0.1 \mathrm{mM}$ DTT in a final volume of $100 \mu \mathrm{l}$ ) (Promega Corp.). Incubation was at $37^{\circ} \mathrm{C}$ for $1 \mathrm{~h}$. Fragments smaller than 200 base

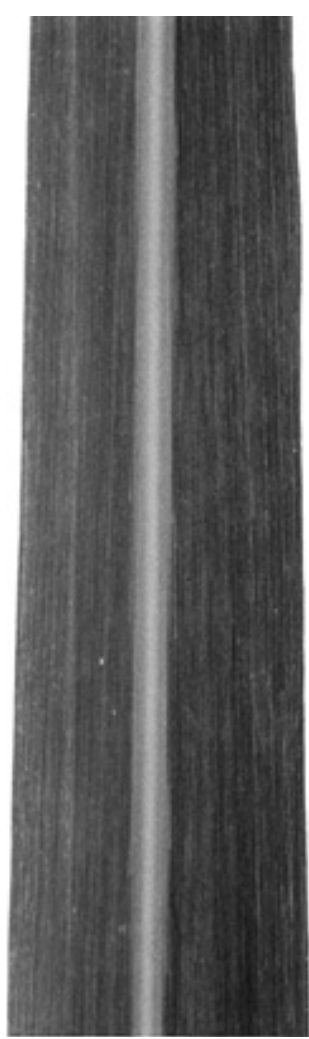

H

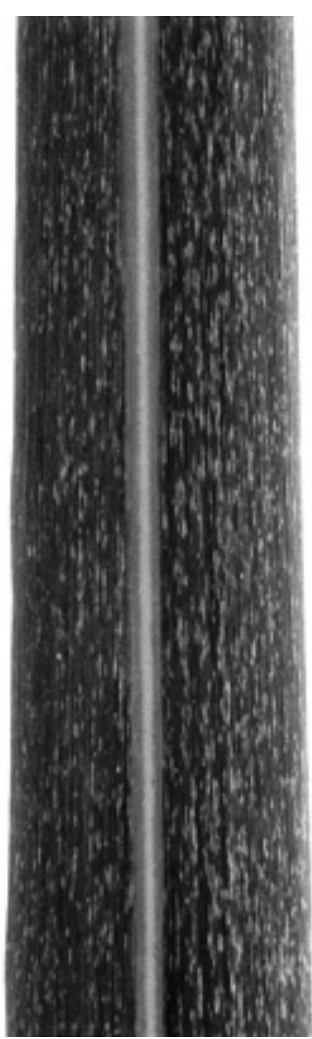

D
Fig. 1. Typical striations on a leaf of sugarcane striate mosaic-affected sugarcane (D) compared with a leaf of normal sugarcane $(\mathrm{H})$. pairs (bp) were removed with a Sephacryl 400 spin column (Pharmacia Biotechnology Inc., Uppsala, Sweden), yielding dsDNA originating at random priming sites within the sequence of the dsRNA, but representative of essentially the whole sequence of the dsRNA. All fragments had the same termini to allow them all to be amplified by PCR with the UN primer (10).

Cloning. Amplification of cDNA was done in a 50- $\mu$ l reaction volume containing $5 \mu \mathrm{l}$ of the second-strand cDNA reaction solution, PCR reaction buffer $(50 \mathrm{mM} \mathrm{KCl} ; 10 \mathrm{mM}$ Tris- $\mathrm{HCl}, \mathrm{pH} 9.2$, at $25^{\circ} \mathrm{C} ; 1 \%$ Triton $\mathrm{X}-100 ; 1.5 \mathrm{mM} \mathrm{MgCl}_{2} ; 500 \mu \mathrm{M} \mathrm{dNTPs}$; and $0.1 \mu \mathrm{M}$ UN primer), and $1 \mathrm{U}$ of Taq DNA polymerase (Promega Corp.). Following denaturation at $94^{\circ} \mathrm{C}$ for $2 \mathrm{~min}$, the mixture was subjected to 30 cycles of amplification $\left(94^{\circ} \mathrm{C}\right.$ for $1 \mathrm{~min}, 55$ to $65^{\circ} \mathrm{C}$ for $1 \mathrm{~min}$, and $72^{\circ} \mathrm{C}$ for $3 \mathrm{~min}$ ), followed by a final extension step of $72^{\circ} \mathrm{C}$ for $5 \mathrm{~min}$. The size range of the PCR products was determined by analytical agarose gel electrophoresis. The products were digested with EcoRI and small fragments removed by Sephacryl chromatography as above. The resulting PCR products were cloned into dephosphorylated pGEM-7Zf(+) (Promega Corp.) (22) and transformed into Escherichia coli (JM 109; Stratagene Inc., La Jolla, CA). Transformed bacterial colonies were selected using the 5-bromo-4-chloro-3-indolyl- $\beta$-D-galactopyranoside system. Minipreps of plasmids from over 60 colonies (22) were digested with EcoRI, analyzed on agarose gels to determine the size of inserts, and Southern blots of the gels were probed with ${ }^{32} \mathrm{P}-\mathrm{cDNA}$ prepared by random priming of the PCR product (22). The specificity of selected clones was also tested by probing dot blots of healthy and diseased sugarcane total nucleic acid extracts, and the purified dsRNA, with cDNA synthesized by random priming of the clones to be tested.

Sequence analysis. Selected clones were sequenced by automatic cycle sequencing (Perkin-Elmer Applied Biosystems, Foster City, CA) and compiled with SeqEd software (Perkin-Elmer Applied Biosystems). Comparisons with sequence data bases were done with the Fasta, Blast, and MPsrch programs in the Internet site of DISC homology search programs $(11,17)$. Alignments were done with Clustal W version 1.4 (23), and the search for motifs was done with Signal Scan version 4.0 (19).

RT-PCR. Total nucleic acid was extracted from healthy and ScSM-affected sugarcane by the cetyltrimethylammonium bromide (CTAB) extraction method (8) and dissolved in sterile water. Aliquots were mixed with the primers $5^{\prime}$ CAAAACTACAGTGGATCCTAGT 3' and 5' CACTGCTAAGCATTATGCCTGT 3' in a 50- $\mu \mathrm{l}$ reaction mixture $(25 \mathrm{mM}$ Tris- $\mathrm{HCl}, \mathrm{pH} 8.3 ; 37.5 \mathrm{mM} \mathrm{KCl} ; 1.5 \mathrm{mM}$ $\mathrm{MgCl}_{2} ; 5 \mathrm{mM}$ DTT; $200 \mathrm{U}$ of M-MLV-RT; $0.3 \mathrm{M}$ 2-mercaptoethanol; $10 \mathrm{mM}$ dNTPs; and $40 \mathrm{U}$ of RNasin). The reaction mix was incubated at $42^{\circ} \mathrm{C}$ for $2 \mathrm{~h}$ to produce cDNA, and then $5 \mu \mathrm{l}$ was added to $50 \mu \mathrm{l}$ of a PCR reaction mixture containing $50 \mathrm{mM} \mathrm{KCl}$; $10 \mathrm{mM}$ Tris- $\mathrm{HCl}, \mathrm{pH} 9.2 ; 1.25 \mathrm{mM}$ primers; and $0.5 \mathrm{U}$ of Taq DNA polymerase (Promega Corp.). Following incubation at $94^{\circ} \mathrm{C}$ for $2 \mathrm{~min}$, there were 30 cycles of $94^{\circ} \mathrm{C}$ for $1 \mathrm{~min}, 50^{\circ} \mathrm{C}$ for $1 \mathrm{~min}$, and $72^{\circ} \mathrm{C}$ for $1 \mathrm{~min}$, with a final extension at $72^{\circ} \mathrm{C}$ for $5 \mathrm{~min}$ (Gene Amp 2400; Perkin-Elmer Corp., Norwalk, CT). Products were analyzed by electrophoresis in a $1.2 \%$ agarose gel, visualized with ethidium bromide, and identified by Southern blot hybridization with ScSM-specific probes (22).

Virus purification. All operations were done in the cold. One kilogram of both healthy and ScSM-affected leaves were stripped of midribs, chopped, and blended with 5 volumes (vol/wt) of extraction buffer (0.1 M Na-K phosphate buffer, $\mathrm{pH} 7.0 ; 10 \mathrm{mM}$ EDTA; and 1\% monothioglycerol). The slurry was filtered through muslin, and Triton X-100 was added to 5\% with stirring for $30 \mathrm{~min}$. Polyethylene glycol (PEG) 6000 was added to $8 \%$ (wt/vol), followed by stirring for $40 \mathrm{~min}$ and centrifugation at $10,000 \times g$ for $10 \mathrm{~min}$. Pellets were resuspended overnight in $200 \mathrm{ml}$ of $10 \mathrm{mM}$ Tris- $\mathrm{HCl}$ ( $\mathrm{pH}$ 7.4). Insoluble material was removed by centrifugation at $10,000 \times g$ for $10 \mathrm{~min}$, and the supernatant was layered over a $20 \%$ sucrose cushion and centrifuged at $150,000 \times g$ for $2 \mathrm{~h}$ 
in the Beckman Ti 60 rotor (Beckman Instruments, Palo Alto, CA). The pellet was resuspended in $23 \mathrm{ml}$ of $10 \mathrm{mM}$ Tris- $\mathrm{HCl}, \mathrm{pH} 7.2$, for at least $6 \mathrm{~h}$. Insoluble material was removed by low-speed centrifugation as above. $\mathrm{Cs}_{2} \mathrm{SO}_{4}(7.5 \mathrm{~g})$ was added, and aliquots of the solution were centrifuged in a Beckman SW $65 \mathrm{Ti}$ rotor at $45,000 \mathrm{rpm}$ for $18 \mathrm{~h}$. Bands were visualized by light scattering and recovered with a syringe, and the remainder of the gradient was collected as $0.5-\mathrm{ml}$ fractions. Each component was dialyzed against $10 \mathrm{mM}$ Tris-HCl, $\mathrm{pH}$ 7.4, centrifuged in a Beckman TLA 100.3 rotor at $103,000 \times g$ for $2 \mathrm{~h}$, and the pellet was resuspended in $10 \mathrm{mM}$ Tris- $\mathrm{HCl}, \mathrm{pH} 7.4$, containing $0.02 \% \mathrm{NaN}_{3}$. Samples from every step of the virus purification procedure were dotted on a nylon membrane (Zeta-probe; Bio-Rad Laboratories) and probed with ${ }^{32}$ P-labeled ScSM-specific DNA. Fractions that hybridized with the ScSM-specific probes were negatively stained with $1 \%$ phosphotungstate, $\mathrm{pH}$ 6.8, on Formvar-coated grids and examined with a Philips CM 100 electron microscope (Philips Electron Optics, Eindhoven, the Netherlands) at $100 \mathrm{kV}$ (18). Virus-like particles were photographed alone and mixed with TMV as an internal size marker, and the electron micrographs were scanned with an image analyzer (Adobe Photoshop LE; Adobe Systems Inc., Seattle) and photoscanner, and measured using a computer analysis program (Kontron KS100; Kontron Elektronik GmbH, Eching, Germany). An aliquot of the high-speed pellet containing virus-like particles was denatured at $100^{\circ} \mathrm{C}$ in gel loading buffer $(50 \mathrm{mM}$ Tris- $\mathrm{HCl}$, pH 6.8; 100 mM DTT; 2\% SDS; $0.1 \%$ bromophenol blue; and $10 \%$ glycerol) and analyzed by electrophoresis in a discontinuous $12 \%$ polyacrylamide-SDS gel (15). To extract RNA, the virus preparation was predigested with RNase $(50 \mathrm{ng} / \mathrm{ml})$ and DNase $(50 \mathrm{ng} / \mathrm{ml})$ for $30 \mathrm{~min}$ at $37^{\circ} \mathrm{C}$ and then digested in proteinase $\mathrm{K}$ $\left(20 \mu \mathrm{g} / \mathrm{ml}\right.$ in $50 \mathrm{mM}$ Tris-HCl, $\mathrm{pH} 7.4$, and $1 \% \mathrm{SDS}$ ) at $37^{\circ} \mathrm{C}$ for $4 \mathrm{~h}$. RNA was analyzed by agarose gel electrophoresis or extracted with phenol-chloroform and precipitated with ethanol.

Detection of polyadenylate with (deoxythymidine) ${ }_{15}$ primer. The extracted RNA precipitate was dissolved in Tris-EDTA (TE; $10 \mathrm{mM}$ Tris- $\mathrm{HCl}, \mathrm{pH} 7.4$, and $1 \mathrm{mM}$ EDTA), and $5 \mu \mathrm{l}$ was mixed with $5 \mu \mathrm{l}$ of $\mathrm{d}(\mathrm{T})_{15}$ primer $(0.5 \mu \mathrm{M})$ and denatured by boiling. A solution containing $1 \times$ M-MLV-RT reaction buffer $(37.5 \mathrm{mM} \mathrm{KCl}$; $25 \mathrm{mM}$ Tris- $\mathrm{HCl}, \mathrm{pH} 8.3 ; 1.5 \mathrm{mM} \mathrm{MgCl}_{2}$; and $5 \mathrm{mM}$ DTT), $1 \mathrm{mM}$ dATP, $1 \mathrm{mM}$ dGTP, $1 \mathrm{mM}$ dTTP, $0.5 \mathrm{mM}$ dCTP, $25 \mu$ Curie of ${ }^{32} \mathrm{P}-$ $\mathrm{dCTP}$, and $200 \mathrm{U}$ of M-MLV-RT was added. The solution was incubated at $42^{\circ} \mathrm{C}$ for $1.5 \mathrm{~h}$ and then fractionated on a SephadexG50 column (22). The nucleic acid fraction was analyzed by electrophoresis on a $1.2 \%$ agarose gel, stained, photographed, transblotted to a nylon membrane, and the products identified by autoradiography. Other samples in this assay included the RNA of PSbMV as a $3^{\prime}$ polyadenylated positive control and nucleic acid extracted from the $20 \%$ sucrose cushion pellet of healthy sugarcane leaves (described in the virus purification procedure above) as a virus negative control.

\section{RESULTS}

Extraction of dsRNA. The microgranular cellulose method (5) yielded small amounts of nucleic acid from leaves of both fieldand glasshouse-grown sugarcane with symptoms of ScSM, whereas preparations from healthy sugarcane contained negligible amounts of nucleic acid. All nucleic acid extracts from diseased cane showed several bands on ethidium bromide-stained agarose gels with an apparent molecular size of approximately 9 kilobases (kb) (using dsRNA size markers from AMV, CMV, TMV, and PSbMV) together with a variable number of lower-molecular-weight bands (Fig. 2). These bands were all resistant to DNase, and to RNase in high salt, but were digested with RNase at low salt concentrations, as expected for dsRNA. No such bands were isolated from sugarcane seedlings or from healthy sugarcane collected in the field outside the region of occurrence of the ScSM disease. Leaves from diseased plants grown in the glasshouse had higher yields of dsRNA than did leaves collected from diseased plants in the field. The additional dsRNA species (6.0 and $2.6 \mathrm{~kb}$ ) were less prominent (Fig. 2), but they hybridized to a probe made from the purified 9-kb dsRNA. There were also some poorly resolved bands below the 2.6-kb band that also hybridized with the $9-\mathrm{kb}$ probe (Fig. 2B). The unique association of the 9-kb dsRNA band with diseased plants indicated that it could be used both as a molecular marker for the disease and as evidence that ScSM is a disease of viral etiology. The dsRNA was, therefore, purified so that it could be cloned and sequence information used to identify the possible viral agent of ScSM disease.

Purification, amplification, and cloning of dsRNA. Purification of the dsRNA by two cycles of gel electrophoresis and inclusion of the DNase and high salt RNase A treatments were essential to avoid cloning of sequences not specific to ScSM. The random PCR method described by Froussard (10) allowed amplification from 50 to $100 \mathrm{ng}$ of purified dsRNA. Optimum conditions for random PCR were a UN-RH primer concentration of $2.5 \mu \mathrm{M}$ and an annealing temperature of $60^{\circ} \mathrm{C}$. Use of a dsRNA-specific probe showed that the PCR products ranged in size from 0.2 to $2 \mathrm{~kb}$ (data not shown). Inserts cloned from the PCR products ranged from 0.22 to about $1 \mathrm{~kb}$ in size. All of the inserts were shown to be homologous to the dsRNA by probing Southern blots with a dsRNAspecific probe. Twenty-four recombinant colonies that hybridized to a labeled dsRNA probe were selected for further analysis.

Selection and sequencing of ScSM-specific clones. Five of the clones were examined in hybridization experiments. Three clones cross-hybridized weakly, whereas the remaining two clones did not hybridize with the others. The five clones, containing inserts of $0.9,0.67,0.63,0.6$, and $0.3 \mathrm{~kb}$, were sequenced. The three crosshybridizing clones were found to have overlapping sequences representing a region of $1.25 \mathrm{~kb}$. The remaining two clones showed no sequence homology with any of the other inserts and were defined as unique regions of 0.63 and $0.67 \mathrm{~kb}$, respectively (Fig. 3).

Comparison of segments with sequences in the genome data base. A comparison of the sequences with the genome data base identified nucleotide sequence similarities between the ScSMspecific segments and a number of rod-shaped viruses in the genera Potex-, Capillo-, Tricho-, Carla-, Fovea-, and Potyvirus, as well as

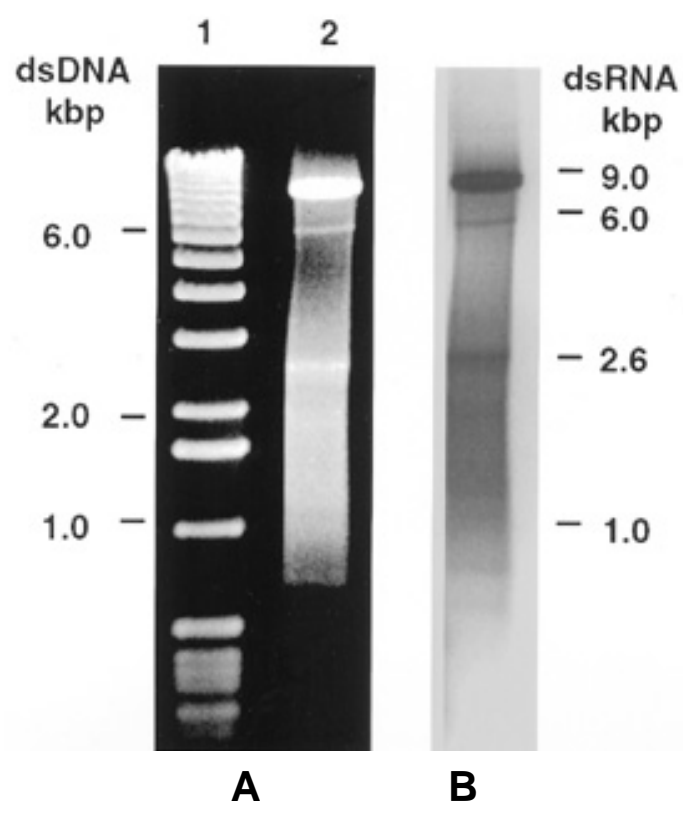

Fig. 2. Double-stranded RNA (dsRNA) associated with sugarcane striate mosaic-affected sugarcane leaf tissue. A, Ethidium bromide-stained agarose gel showing DNA size marker in lane 1 and dsRNA in lane 2. B, Northern blot of gel probed with ${ }^{32} \mathrm{P}$ cDNA synthesized from purified 9-kilobase (kb) dsRNA. A major band is visible at the 9-kb position with minor bands at 6 and $2.6 \mathrm{~kb}$ and multiple indistinct smaller bands. Size markers are dsRNA from pea seedborne mosaic virus and alfalfa mosaic virus. 


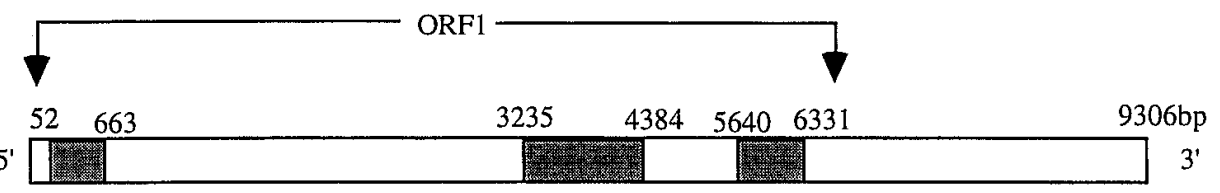

ASPV
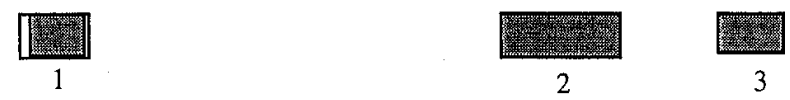

ACCCTAAGCAGCTCTTAATCGCTCAATTGTCCTCTGAAGAGCAGGCCAGAATTACCAGCTCTGTGACACGAAAGTTAGCGCAGGAGGAAGAGAATGATCA

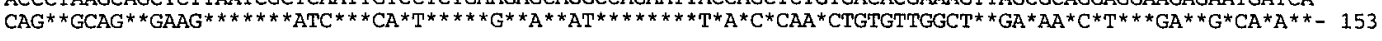
AGGTTTATTCAGTTATCATGTCTCTCCAACTGTGCAGA-GAAGTTGATCAAGTCTGGTGTCAACTCTGTGCCTACTCCTTCTGATGTACATAGTCATCC

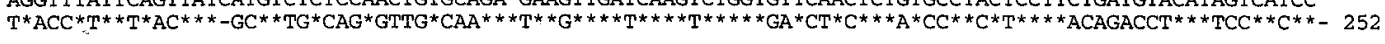
TTGTTGTAAAATGCTAGAAAATCATATTTTATACAGAGTTCTTCCTTCTTATGTAGATTCAGATTTTATCCTTGTAGGTATTAAGCATTCTAAGTTAGCC

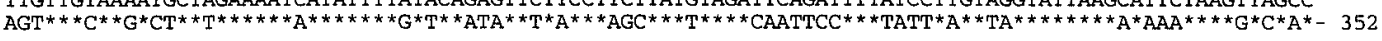
TTTCTTAAACCAAGAGGCGCGAAAAAGAATGTTGATCTTTCAACTGTTAAGGTGCTCAATCGTTTTGTCACAATTCTTGACAGATCCAGGTTATGGTAAA

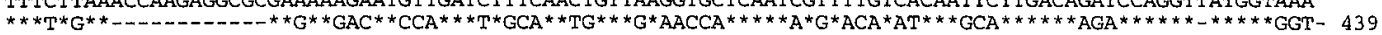
GAAGTTTAATCACCTCAATATCATGTCAACATTCACTCCCTGAACCTAAGGGTAGCAGTTCCTATACCCCCTGAAACTTTAAAACCCTAATTCCCCAAT

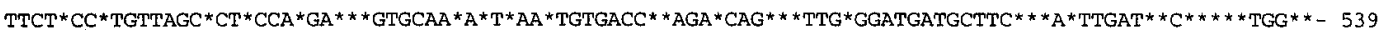
CTGGAGCGAATTTAAGGGCCACAAACTTTTTTTTCCCATGAATGAAGTTTGCATTACTGGAAGGGATGAATCCTATATAAAATGCTATCATCCTTTAGA

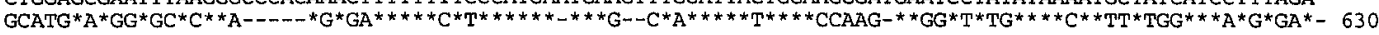
GCCTCAGTATGTTACGCACTATGTATGCCACCC \#» CCCCCTGCAAAGATTGATTTCATAGATGGGTACATCAAAACTACGG---TGGAT

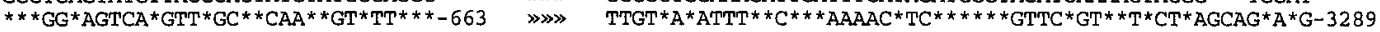

CCTAGTCTTGATTCTCGGTTAACATGCATCAATGTACCCGCAGATGGTGATTGTTTTTGGCATAGTGTATCTCTTTATCTTGGTGTTGAGGCCAA--AAT

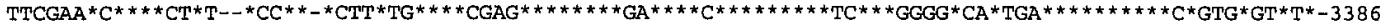

GATCAAAGATGCAGC-TGTTCTAAGAAACAGGAATCA---CAAAAATGCCAGATTAGTTGAGCAAATGGGTGATAAAGTTTGGGCTGAAGATGAGGCTAT

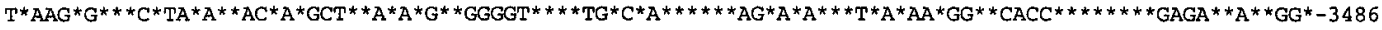
ACTAGACTGTGCATGTTTTTACAACTTGATTATACGTATAGTA-TTTGAACATGAATTGCATACATACAGTCCCAATGATTTGATGAGGATACAACTGA

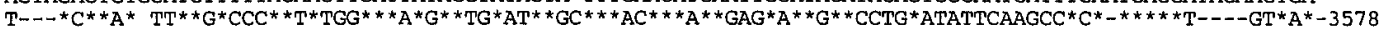
GGTTTGGCTCAAAAATTTGG-ATCATATGCATTTTTGTCCAGCAAAGTTCATAAATTCTTGTGTCATTGATGCAATCTCTAAAGCAGTTGACATTCCGCC

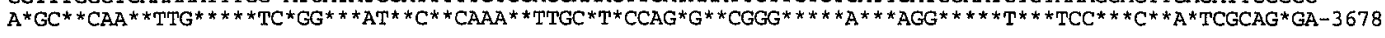
TTTGATGTACAAAGAATGATATCTTCACAGGAGAGTCTTCACTCCGAGTATGAGAGATTGAGCAGTGGGAAATCCTTTGATCTCCTTGGACTGGAGAGT

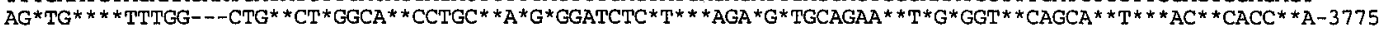
TTGATGACTTTCTTCAACATAGGGGCTGAAGTACAGGAAAATGGTCACAAGTTTATTTTGAGCGAGAATGGCAGTAGGGCTCGAAGCTTCATTCTGGAGA

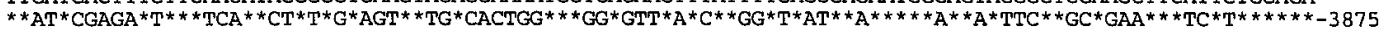
ATAATCATATTGAATTGTTGCTGGAGATAGAAAGGATCTAAGAAAGGAGGGAGTTGGGTTTGTTAAGCTAATGAATGCAAATCAAAGTAAGTCTGTGCT

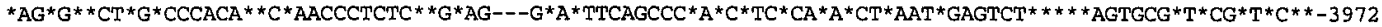
GTCTCPCGCCTGCTCAAAGGTTAAATACACCCCATCTTATGACAGAGCCTTTAAACTGTCAAAAGCTPTTGCTAATGGTTATACAGGCATAAT--GCTTA

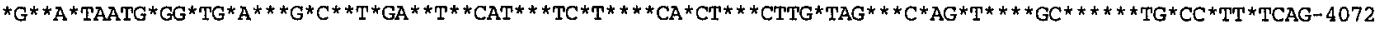

GCAGTGAAAAA--TTTGGCGAGATTGA-------AATCAATGGTAAGAATG----ACGAGAGGGAAATCAATGTTATGATGGGAACATTTGGGGCTGGAA

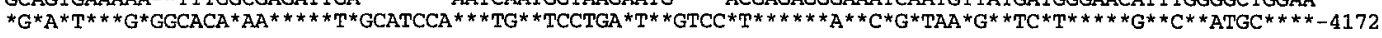
AGACTAGAGTATTTGTGGATTATATTCAGGCTTACTCTGGTAGAGGTTPATTTTATGTTAGCCCAAGAAAGAACCTTAAGGAGCTTITCGATAACTCTGC

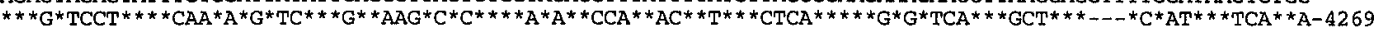
CATCCAGGCAGTTCAAGGCTTTAAAACCAAGTCAAGTGACAAGAAAGGCAGTGTAAAGAGTTTTCATAGCTCTTTCACCTTTGAGACTGCTATAATGAAA

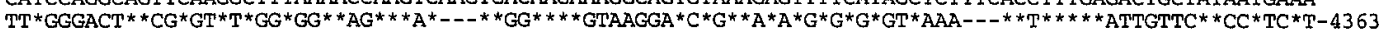
GCCGGCCAGATTGGCGATGATTCAATTCTTATTATAGACGAGATTCAGCTCTATCCGCCTGGCTACCTTGATTTAATCCTTCTATTGATACCTTCAAGTT

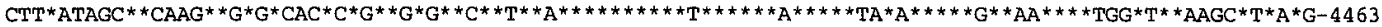
GCATGGTAATTTGTGCTGGT »»» ATCGAAGACACTCACTGCCAATTGATATTGCTGATATATTCATGAAGTCACAACTCTGCACAAAAAT

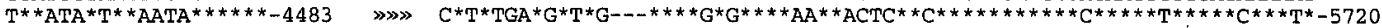
GGAGAGTATGTTCTGCGAGGCAAAGGCTGGTCAGACTTTAGCTTGTTTCCATCATGTAGTTCTTGCACGATTTTCTCCATGGGTCCGTTACATAGAAAAG

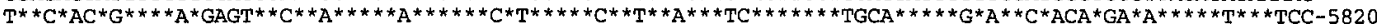

AAGCTGGTCAGTTCACTGCCAGATAATTACTATATACACTCTGGAAAGAACTTTGATCAACTCAATGCTTGGGTTAAGGCAAACAATTITGTGGGTGAAT

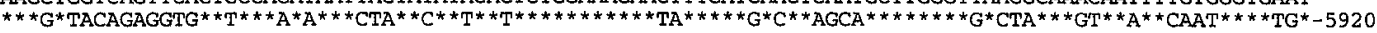
GCACTGAATCGGATTATGAGGCCTTTGATGCAAGTCAAGATCACTATATACTGGCCTTTGAATTAGCATTAATGAAGTACCTTGGTCTACCCAATGAGTT $\star \star \star \star C^{\star \star} G^{\star *} T^{\star \star \star \star \star \star \star \star \star \star ~}$ GATAGAGGACTACAAGTACATTAAGATTCATTTGGCTCAAAATTGGGTGATTTGCCATAATGAGATTCACCGGTGAAGCCAGCACTTTCTTATTTAACA

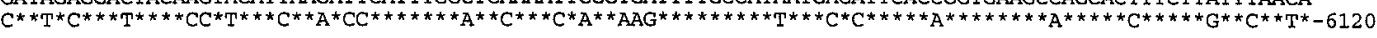
CAATGGCAAATATGCTTTTCACTTTTCTGGTCTATGATATCAAAGGCAATGAGTCAATTTGCTTTGCTGGCGATGACATGTGTGCAAATACAAGTCTTAA

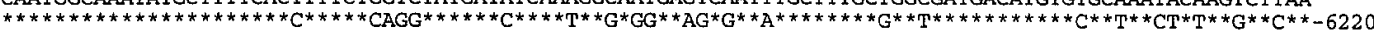
GACATGCGGCAAGAACAAAAGTTTGCTCAAAAAGTTTACACTCAAAGCTAAAGTTCAGGTAACTGAAAGCCCAACATTTTGCGGATGGCACTTGACTGAG

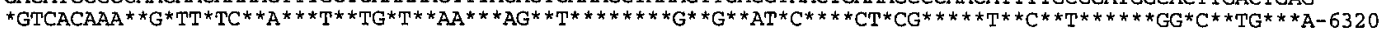
GATG

$C^{\star \star \star}-6324$

Fig. 3. Top, Diagram showing the regions within ORF1 of the apple stem pitting virus (ASPV) genome in which regions 1, 2, and 3 of sugarcane striate mosaic (ScSM)-associated RNA have greater than 51\% nucleotide sequence homology (shaded zones). Bottom, Sequences of the cloned regions 1, 2, and 3 of ScSMassociated RNA showing alignment (upper row) with similar regions in the sequence of ASPV (lower row). Identical nucleotides are indicated with asterisks and (-) is inserted to adjust the alignment. Multiple arrowheads indicate the position of discontinuities in the sequence comparison. Numbers refer to nucleotide positions in the ASPV sequence. 
one virus in the icosahedral virus genus Tymovirus (Table 1). $\mathrm{ScSM}$ region 3 had significant sequence similarity to viruses in all seven genera and region 1 had significant similarity to viruses in the genera Tricho- and Carlavirus, whereas ScSM region 2 had significant similarity to only three viruses in the genus Carlavirus. The genome-sense orientation of the three regions was determined from this comparison. The strongest overall similarity was observed with species within the genus Carlavirus and with the type member of the genus Foveavirus, apple stem pitting virus (ASPV). The greatest similarity was found within the sequence of the putative replicase gene (ORF1) of ASPV (Table 1). Figure 3 shows the sites on the ASPV genome map that matched the ScSM regions 1, 2 , and 3 and the best-fit alignment of the three ScSM regions within the ORF1 of ASPV. Marked variation in the degree of similarity between the sequences is evident. For example, region 3 showed the highest homology with ASPV, whereas region 2 showed the lowest (Table 1). In region 1, part was similar (shaded region), whereas both the $5^{\prime}$ and $3^{\prime}$ ends were dissimilar (Fig. 3). These similarities strongly supported the conclusion that the sequence obtained from ScSM-affected sugarcane was from a ScSM-associated virus $(\mathrm{ScSMaV})$ and that this virus was likely to be rod-shaped and allied to carlaviruses and ASPV.

Virus purification. The pellet from the sucrose cushion step prepared from ScSM-affected plants and a fraction from the isopycnic density gradient hybridized to the probe made from the ScSM-associated dsRNA, whereas the same fractions from healthy sugarcane were negative. Filamentous virus-like particles were observed in a high-speed pellet from the positive isopycnic gradient fraction (Fig. 4). Because the particles were isolated only from

TABLE 1. Percent nucleotide sequence similarity between the three regions cloned from sugarcane striate mosaic ( $\mathrm{ScSM}$ )-associated double-stranded RNA and viruses in seven genera

\begin{tabular}{|c|c|c|c|}
\hline \multirow{2}{*}{$\begin{array}{l}\text { Genus } \\
\text { Species }^{\mathrm{a}}\end{array}$} & \multicolumn{3}{|c|}{ ScSM-associated RNA region ${ }^{b}$} \\
\hline & 1 & 2 & 3 \\
\hline \multicolumn{4}{|l|}{ Potexvirus } \\
\hline WCIMV & $\ldots$ & $\ldots$ & 53.7 \\
\hline BaMV & $\ldots$ & $\ldots$ & 53.3 \\
\hline PapMV & $\ldots$ & $\ldots$ & 52.0 \\
\hline \multicolumn{4}{|c|}{ Capillovirus } \\
\hline ASGV & $\ldots$ & $\ldots$ & 59.6 \\
\hline CCA & $\ldots$ & $\ldots$ & 64.7 \\
\hline CTLV & $\ldots$ & $\ldots$ & 58.8 \\
\hline \multicolumn{4}{|l|}{ Trichovirus } \\
\hline ACLSV & 56.5 & $\ldots$ & 60.1 \\
\hline GVB & 58.9 & $\ldots$ & 56.3 \\
\hline PVT & $\ldots$ & $\ldots$ & 61.8 \\
\hline \multicolumn{4}{|l|}{ Carlavirus } \\
\hline BISV & $\ldots$ & $\ldots$ & 67.7 \\
\hline GLV & $\ldots$ & $\ldots$ & 65.8 \\
\hline GarMV & $\ldots$ & $\ldots$ & 64.9 \\
\hline PVM & 59.9 & $\ldots$ & 63.7 \\
\hline PVS & $\ldots$ & $\ldots$ & 68.1 \\
\hline ShVX & $\ldots$ & $\ldots$ & 63.0 \\
\hline \multicolumn{4}{|l|}{ Foveavirus } \\
\hline ASPV & 57.9 & 51.6 & 67.6 \\
\hline \multicolumn{4}{|l|}{ Potyvirus } \\
\hline PRSV & $\ldots$ & $\ldots$ & 52.6 \\
\hline \multicolumn{4}{|l|}{ Tymovirus } \\
\hline OYMV & $\ldots$ & $\ldots$ & 52.6 \\
\hline
\end{tabular}

a Acronym and GenBank accession numbers of viruses: ACLSV, apple chlorotic leaf spot virus (D14996); ASGV, apple stem grooving virus (D14995); ASPV, apple stem pitting virus (D21829); BaMV, bamboo mosaic virus (D26017); B1SV, blueberry scorch virus (L25658); CCA, cherry capillovirus A (X82547); CTLV, citrus tatter leaf virus (D14455); GarMV, garlic mosaic virus (D11161); GLV, garlic latent virus (Z68502); GVB, grape vine virus B (X75448); OYMV, ononis yellow mosaic virus (J04375); PapMV, papaya mosaic virus (D13957); PRSV, papaya ring spot virus (X67673); PVM, potato virus M (D14449); PVS, potato virus S (D00461); PVT, potato virus T (D10172); ShVX, shallot virus X (M97264); and WCIMV, white clover mosaic virus (D13957).

b $\ldots=$ Nucleotide sequence homology below $40 \%$.
ScSM-affected plants and their nucleic acid was homologous with the disease-associated dsRNA, it was assumed that they were the particles of a ScSMaV. The yield of particles was too low to attempt an infectivity assay by mechanical inoculation.

Characteristics of ScSMaV. ScSMaV particles were $15 \mathrm{~nm}$ in diameter and 400 to $3,400 \mathrm{~nm}$ long, with a bimodal distribution. The major component $(n=115)$ was in the size class 800 to $1,000 \mathrm{~nm}$, with a mean length of $950 \mathrm{~nm}( \pm 50 \mathrm{~nm})$. The minor component $(n=$ 54) was in the size class 1,800 to $2,000 \mathrm{~nm}$, with a mean length of $1,900 \mathrm{~nm}( \pm 100 \mathrm{~nm})$. A single protein band of about $51 \mathrm{kDa}$ was observed in SDS-polyacrylamide gel electrophoresis (PAGE), which is assumed to be the capsid protein of ScSMaV. No proteins were detected in the comparable fraction from healthy sugarcane. A 9-kb single-stranded RNA (ssRNA) with homology to the ScSM-specific probe was isolated from the particle preparation (Fig. 5). When $\mathrm{d}(\mathrm{T})_{15}$ primers were used for cDNA synthesis using the 9-kb ssRNA isolated from the $\mathrm{ScSMaV}$ preparation as a template, primer extension occurred. The products for both the ScSMaV RNA and the polyadenylated RNA from PSbMV gave an essentially identical pattern in which they fell in the apparent size range of 0.3 to $4 \mathrm{~kb}$.

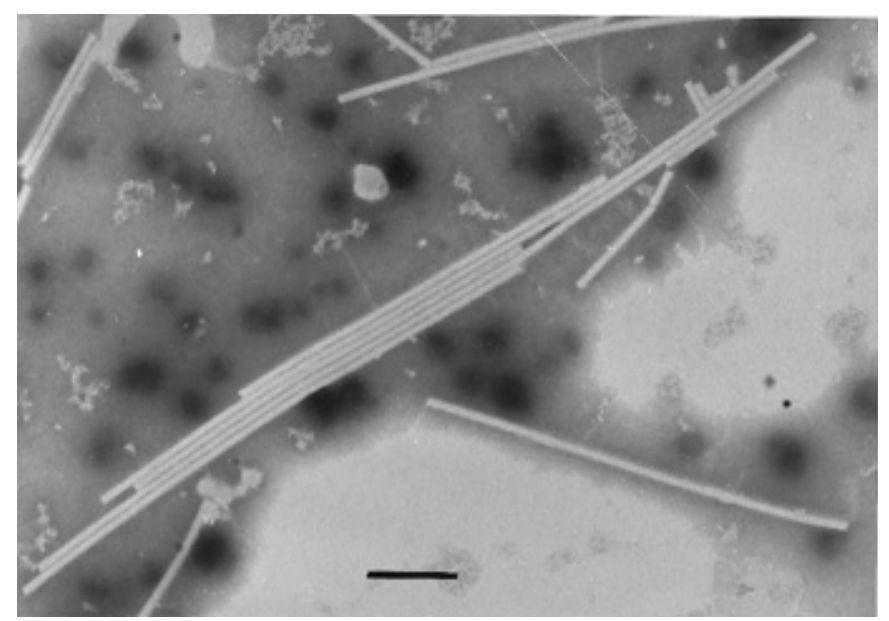

Fig. 4. Electron micrograph of slightly flexuous rod-shaped particles observed in a preparation enriched with sugarcane striate mosaic-associated RNA. Grids were negatively stained with phosphotungstate. The bar represents $200 \mathrm{~nm}$.
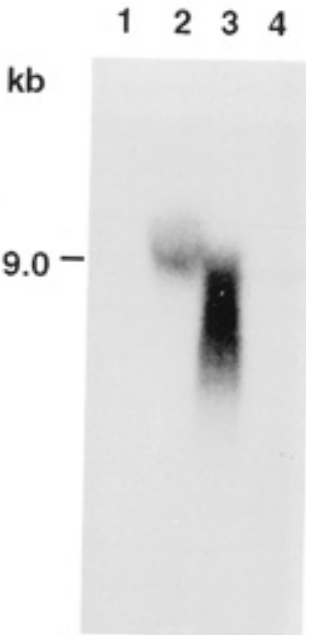

Fig. 5. Northern blot hybridization of nucleic acid extracted with proteinase $K$ from partially purified sugarcane striate mosaic (ScSM)-associated virus, fractionated by agarose gel electrophoresis and probed with cDNA representing the sequence in region 3 of ScSM-associated RNA. The size marker was singlestranded RNA (Promega Corp.). Lane 1, Nucleic acid treated with RNase A (100 ng/ml in $50 \mathrm{mM}$ Tris- $\mathrm{HCl}, \mathrm{pH} 7.0$, and $0.3 \mathrm{M} \mathrm{NaCl}$ at $37^{\circ} \mathrm{C}$ for $30 \mathrm{~min}$ ); lane 2, untreated nucleic acid; lane 3 , as in lane 2 but further extracted with phenolsodium dodecyl sulfate; and lane 4 , total nucleic acid from normal sugarcane. 
Moreover, the incorporation of radioactivity into the ScSMaV product was proportional to the amount of RNA added to the reaction mixture. In contrast, nucleic acids extracted from the sucrose pellet stage of a preparation from normal sugarcane gave no primer extension. This result is consistent with ScSMaV RNA having a 3' polyadenylic acid tract.

RT-PCR assay. When a total nucleic acid extract from a diseased plant was used as the template in RT-PCR, a ScSM-specific band (820 bp) was detected in an analytical agarose gel that hybridized to the ScSM-specific probe (Fig. 6). When a range of diseased samples was assayed, the product showed variable intensity in the first round of RT-PCR, but reamplification of aliquots from these samples with PCR showed high concentrations of specific DNA in all samples from diseased plants, while the disease-free control remained negative.

\section{DISCUSSION}

Determination of the cause of a disease of unknown etiology relies either on the isolation of an intact agent by biological or physical means or the detection of a nonhost component that is associated with the disease. The latter approach can be termed 'component analysis', and it may be applied to protein (16) or nucleic acids. Nucleic acid component analysis is preferable not only because disease-associated unique nucleic acids can implicate a virus-like agent, but also because it indicates its likely genomic organization, its possible taxonomic position, and leads to the development of nucleic acid-based diagnostic probes $(7,20)$.

$\mathrm{ScSM}$ has many characteristics of a soilborne virus disease, but early studies (12) had failed to identify a virus agent. In a search for a virus by nucleic acid component analysis, a disease-associated dsRNA was identified (4). However, the CF11 cellulose binding method that was used (7) for isolating dsRNA from sugarcane

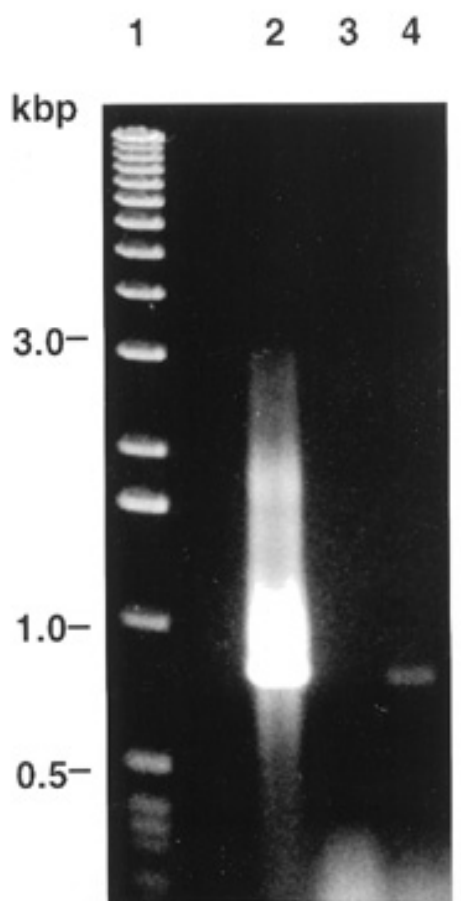

A

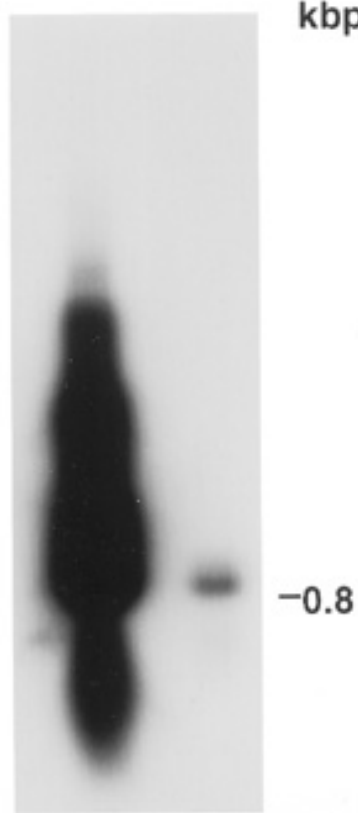

B
Fig. 6. Analysis of reverse-transcriptase polymerase chain reaction products from total nucleic acids of sugarcane striate mosaic (ScSM)-affected sugarcane. Products were A, fractionated by $1.2 \%$ agarose gel electrophoresis and $\mathbf{B}$, subjected to northern blot analysis using ${ }^{32} \mathrm{P}$ cDNA representing the sequence in region 2 of ScSM-associated RNA. Lane 1, 1-kilobase ladder; lane 2, 820 -base pair product from segment 2 , used as a positive control for the reaction; lane 3 , product from total nucleic acid of healthy sugarcane leaf; and lane 4, product from nucleic acid of ScSM-affected sugarcane leaf. tissue gave low yields that were insufficient for purification and cloning. We, therefore, used the more efficient microgranular cellulose binding method for isolating dsRNA (5).

A 9-kb dsRNA isolated from ScSM-affected sugarcane leaves was shown to be associated with the disease. The additional 6- and 2.6-kb dsRNAs represent fragments related to the 9-kb RNA because of their sequence homology in northern blots. No asymptomatic samples contained detectable dsRNA either by staining, analysis with 9-kb dsRNA-specific probes, or RT-PCR, whereas all samples from diseased plants from six different sites contained 9-kb dsRNA. The dsRNA, therefore, could be used as a molecular marker for ScSM disease, as well as indicating that it had a probable viral etiology.

The first attempts at cloning showed that the dsRNA was contaminated with other sequences. Cloning of ScSM-specific genomic fragments was successful after contaminants were removed by treating preparations with DNase and then RNase in high salt, before gel fractionation, as well as omitting all DNA size markers from the gel fractionation procedures. The small amounts of purified dsRNA that were recovered were successfully amplified by random PCR. The annealing step in the PCR was done at $60^{\circ} \mathrm{C}$ instead of $55^{\circ} \mathrm{C}(10)$ to maximize specificity. Optimization of the primer concentration was necessary because the PCR products were found to be reduced in size when a large excess of the UN-RH primer was used.

The nucleotide sequences obtained from the dsRNA represented $2.55 \mathrm{~kb}$ of the estimated $9 \mathrm{~kb}$ of the ScSM-specific RNA. A homology search showed that the three sequenced regions had some identity with two species within the genus Carlavirus and with ASPV $(13,14)$ in the genus Foveavirus (International Committee on Taxonomy of Viruses, unpublished data). Overall, the greatest similarity was with the ASPV ORF1, which is the putative replicase region (13). Less but significant similarity was observed with other genera, representing both rod-shaped viruses and one icosahedral virus genus, the genus Tymovirus, for which replicase similarities with rod-shaped viruses have been reported (2).

These sequence data indicated that there was a strong possibility that the agent of ScSM was a rod-shaped virus. A general virus purification procedure was adopted to identify fractions enriched for the disease-specific sequences, and we found unusual rod-shaped virus particles $(\mathrm{ScSMaV})$ associated with the RNA sequence in the final preparation. The particles were $15 \mathrm{~nm}$ in diameter with mean modal lengths of 950 and $1,900 \mathrm{~nm}$. We conclude that the shorter length represents a monomer and that the longer represents a dimer of the particle. This would be consistent with the virus-associated 9-kb ssRNA being encapsidated in the 950-nm particle. The monomeric length exceeds that for the carlaviruses $(610$ to $700 \mathrm{~nm})$ (2) and ASPV (800 nm) (14). The particles showed slight flexibility, similar to that described for the carlaviruses but different from that described for the highly flexuous ASPV (14). The 51-K putative capsid protein of $\mathrm{ScSMaV}$ is larger than that of both carlaviruses $\left(M_{\mathrm{r}}\right.$ of 31 to $\left.36 \mathrm{~K}\right)(2)$ and ASPV $\left(M_{\mathrm{r}}\right.$ of 44 or $\left.48 \mathrm{~K}\right)(13,14)$.

This experimental approach has allowed us to develop a PCR assay specific for $\mathrm{ScSMaV}$ and to confirm that it is associated with ScSM. Although thin sections of cells of ScSM-affected sugarcane examined by electron microscopy failed to show virus particles, they showed distorted thylakoids, enlarged plasmodesmata, and phytoplasma-like particles (3). The presence of phytoplasmas in some of our sugarcane samples was confirmed by PCR (3), but unlike the virus, they were shown not to be specifically associated with the mosaic symptoms of ScSM disease.

In conclusion, we have identified a virus of unusual characteristics that is associated with $\mathrm{ScSM}$. This virus, $\mathrm{ScSMaV}$, has sequence and particle characteristics that distinguish it from established plant virus groups. It appears to be more closely related to ASPV than to other described viruses, and we propose that it should be tentatively classified with this virus until the full sequence of ScSMV RNA is available for a further comparison. 


\section{ACKNOWLEDGMENTS}

Financial assistance was provided by C. C. Ryan, director of the Bureau of Sugar Experiment Stations (BSES), and the Burdekin Crop Protection and Productivity Boards. We thank R. C. Magarey of the BSES, Tully, Queensland, for providing plant material for this study; and M. A. Rezaian for helpful discussions.

\section{LITERATURE CITED}

1. Anonymous. 1969. Page 66 in: Annual Report. Bureau of Sugar Experiment Stations, Indooroopilly, Australia.

2. Brunt, A. A. 1995 . Genus Carlavirus. Pages $475-478$ in: Virus Taxonomy: Sixth Rep. Int. Comm. Taxon. Viruses. F. A. Murphy, C. M. Fauquet, D. H. L. Bishop, S. A. Ghabrial, A. W. Jarvis, G. P. Martelli, M. A. Mayo, and M. D. Summers, eds. Springer-Verlag, Vienna.

3. Choi, Y. G. 1997. The etiology of sugarcane striate mosaic disease. Ph.D. thesis. The University of Adelaide, Adelaide, Australia.

4. Choi, Y. G., and Randles, J. W. 1995. Studies on the etiology of sugarcane striate mosaic disease. Page 84 in: Proc. Biennial Australas. Plant Pathol. Soc. Conf., 10th. Australasian Plant Pathology Society, Toowoomba, Australia.

5. Choi, Y. G., and Randles, J. W. 1997. Microgranular cellulose improves dsRNA recovery from plant nucleic extracts. BioTechniques 23:610-611.

6. Croft, B. J., and Smith, G. R. 1996. Major diseases affecting sugarcane production in Australia and recent experiences with sugarcane disease in quarantine. Pages 55-58 in: Sugarcane Germplasm Conservation and Exchange. ACIAR Proc. 67. B. J. Croft, C. M. Piggin, E. S. Wallis, and D. M. Hogarth, eds. Australian Centre for International Agricultural Research, Canberra.

7. Dodds, J. A. 1993. dsRNA in diagnosis. Pages 273-294 in: Diagnosis of Plant Virus Diseases. R. E. F. Matthews, ed. CRC Press, Boca Raton, FL.

8. Doyle, J. J., and Doyle, J. L. 1990. Isolation of plant DNA from fresh tissue. Focus 12:13-15.

9. Dulieu, P., and Bar-Joseph, M. 1988. Rapid isolation of double stranded RNA segments from disulfide crosslinked polyacrylamide gels. J. Virol. Methods 24:77-84.
10. Froussard, P. 1992. A random-PCR method (rPCR) to construct whole cDNA library from low amounts of RNA. Nucleic Acids Res. 20:2900.

11. Gotoh, O. 1982. An improved algorithm for matching biological sequences. J. Mol. Biol. 162:705-708.

12. Hughes, C. G. 1961. Striate mosaic: A new disease of sugarcane. Nature 190:366-367.

13. Jelkman, W. 1994. Nucleotide sequences of apple stem pitting virus and of the coat protein gene of a smaller virus from pear associated with vein yellows disease and their relationship with potex- and carlaviruses. J. Gen. Virol. 75:1535-1542.

14. Koganezawa, H., and Yanase, H. 1990. A new type of elongated virus isolated from apple trees containing the stem pitting agent. Plant Dis. 74: 610-614.

15. Laemmli, U. K. 1970. Cleavage of structural proteins during the assembly of the head of bacteriophage T4. Nature 227:680-685.

16. Lane, L. C. 1992. A general method for detecting plant viruses. Pages 117 in: Plant Diseases of Viral, Viroid, Mycoplasma and Uncertain Etiology. K. Maramorosch, ed. West View Press, Boulder, CO.

17. Lipman, D. J., and Pearson, W. R. 1985. Rapid and sensitive protein similarity searches. Science 227:1435-1441.

18. Milne, R. G. 1993. Electron microscopy of in vitro preparations. Pages 215-251 in: Diagnosis of Plant Diseases. R. E. F. Matthews, ed. CRC Press, Boca Raton, FL.

19. Prestrige, D. S. 1991. Signal Scan 4.0: A computer program that scans DNA sequences for eukaryotic transcriptional elements. Comput. Appl. Biosci. 7:203-206.

20. Randles, J. W. 1993. Strategies for implicating virus-like pathogens as the cause of diseases of unknown etiology. Pages 315-332 in: Diagnosis of Plant Virus Diseases. R. E. F. Matthews, ed. CRC Press, Boca Raton, FL.

21. Randles, J. W., Hanold, D., and Julia, J. F. 1987. Small circular singlestranded DNA associated with foliar decay disease of coconut palm in Vanuatu. J. Gen. Virol. 68:273-280.

22. Sambrook, J., Fritsch, E. F., and Maniatis, T. 1989. Molecular Cloning: A Laboratory Manual, 2nd ed. Cold Spring Harbor Laboratory Press, Cold Spring Harbor, NY.

23. Thompson, J. D., Higgins, D. G., and Gibson, T. J. 1994. CLUSTAL W: Improving the sensitivity of progressive multiple sequence alignment through sequence weighting, position-specific gap penalties and weight matrix choice. Nucleic Acids Res. 22:4673-4680. 